\title{
Political Jurisprudence or Institutional Normativism? Maintaining the Difference Between Arendt and Fuller
}

\author{
Michael Wilkinson
}

\section{Introduction}

Might jurisprudence more profitably interrogate the relationship between law and politics, than between law and morality? Such is a key, albeit embryonic, contention in Rundle's paper, which pursues this possibility by juxtaposing the work of a philosopher of the 'rule of law,' Lon Fuller, with a theorist of 'the political,' Hannah Arendt.

The enterprise of constructing a 'political jurisprudence' is much closer to Arendt than to Fuller, an asymmetry that creates a tension in their pairing. For although Arendt had only a sketchy, suggestive account of law, Fuller has no discernible account of 'the political' at all. It is illustrative in this regard that his jurisprudential enquiry is directed at the principles of social order. ${ }^{1}$

In many ways Fuller resembles an orthodox representative of a jurisprudential school which has been neatly labelled 'normativist,"' placing the thesis of legal normativity qua moral normativity centre stage - either in the positivist tradition through denial or in the non-positivist tradition by affirmation. It can easily be forgotten that these normativist jurists of either stripe share a conceptual terrain of legal-moral enquiry, which is far from exhausting the field. From outside of this narrow terrain - from the perspective of a political jurisprudence -, the similarities between positivists and their adversaries such as Fuller can appear more significant than the differences.

Fuller, to be sure, is more circumspect than many in the non-positivist tradition regarding the nature of morality, noting that despite an 'almost unwanted abundance' of definitions of law, regarding morality, it seems, mistakenly, 'to be assumed that everyone knows what the second term of the comparison

1 It is telling that Fuller's collection is entitled 'the principles of social order,' but with barely a social theorist or sociologist in sight: Weber, Durkheim, Parsons are conspicuous only by their absence. When considering foundational issues, Fuller speaks of the 'order creating process,' but this remains unexplained, see Lon L. Fuller, Principles of Social Order: Selected Essays of Lon Fuller, ed. K. Winston (Oxford: Hart Publishing, 2001), 290.

2 See, e.g., Martin Loughlin, Idea of Public Law (Oxford: Oxford University Press, 2004). 
embraces.' ${ }^{3}$ But although acknowledging the pervasive ambiguities of moral discourse, Fuller's gaze is never turned towards an exploration of the political dimensions of juristic discourse.

The turn towards exploring the relation between law and politics rather than - or at least in addition to - the relation between law and morality permits a welcome departure from the sterility of much contemporary legal philosophy. In that regard, Rundle's project is most welcome. The concept of the political is conspicuous only by its absence from twentieth-century jurisprudence, with the notable exception of the German jurist Carl Schmitt. ${ }^{4}$ And what is significant about Hannah Arendt's contribution to this potential reorientation of the field is that she offers an alternative and competing concept of the political from that offered by Schmitt, based on action rather than decision, power as opposed to violence, and plurality in place of unity.

But, significantly, what Schmitt and Arendt share as theorists of 'the political' is a concern for the nature and origins of political order and disorder, a concern which brings their work into line with the 'great tradition' of philosophy that begins with Plato and ends with Marx, as Arendt puts it, and which appears to have gone missing from modern analytical jurisprudence, whether positivist or nonpositivist in style. It is certainly absent from Fuller's own work. ${ }^{5}$ It is also largely absent from Rundle's reorientation of the field, at least at the present stage of her project.

What Rundle sketches instead is an institutional jurisprudence, presenting a concrete institutional order as a necessary support for the rule of law, but whose nature remains obscure (section 2). This institutional order (or 'complex' as Rundle sometimes puts it) not only remains vague but also alien, a source of authority that is heteronomous and resolutely 'top-down' rather than 'bottom-up' (section 3). ${ }^{6}$ The image of authority implicit in this account raises the spectre of Hobbes (section 4). Remaining faithful to Arendt, however, would require attend-

3 Lon L. Fuller, The Morality of Law (New Haven: Yale University Press, 1964), 3-4. Fuller himself of course outlines two concepts of morality, a 'morality of duty' and a morality of 'aspiration.' (Rundle acknowledges that Fuller himself had an 'awkward' relationship with the concept of 'morality.')

4 See, most notably, Carl Schmitt, The Concept of the Political, trans. George Swab (Chicago: University of Chicago Press, 2007).

5 Kelsen is illuminating here. More than any other legal theorist his theoretical framework exposes the difficulties and ultimate futility of attempting to capture legal normativity by working through in a systematic, autonomous and pure route to its legal origins. The failures of the pure theory of law are instructive precisely because they illuminate the limits of positivism. It is instructive too that even Hart, in outlining an austere concept of law felt compelled to provide some account of its origins, with the consequent ambiguities of his 'fable,' 'myth' or 'thought experiment' of the move from primitive to modern legal order proving so troublesome. See, for discussion, e.g., Michael Wilkinson, 'Is Law Morally Risky?,' Oxford Journal of Legal Studies 30(3) (2010): 441-66.

6 In an earlier version of her paper Rundle used the language of 'bottom-up' to describe her approach - eds. 
ing to the phenomenon of political freedom, and to the foundation, constitution and augmentation of political authority (section 5). This would provide the groundwork for developing a genuinely political jurisprudence (section 6), a development which, I conclude, is in an important sense antagonistic rather than complementary to Fuller's project.

\section{Institutional jurisprudence}

The recurrent use of the term 'institutional' in Rundle's analysis hints at the superficiality of analyzing the legal subject through the lens of the sheer positive law and, conversely, at the priority of interrogating the political order behind it. ${ }^{7}$ And if institutionalism, which conveys the need for a pre-existing order to support the everyday functioning of the positive law and the legal system, is the implicit leitmotif in Rundle's paper, it is notable that this reflects the turn Carl Schmitt himself took to overcome the duality of normativism and decisionism, by capturing a third category of 'concrete order thinking.' ${ }^{8}$ Institutions, for Schmitt, and the French jurist Hauriou who influenced him, provide the basis for legal order, for they provide the 'duration, continuity, and reality' necessary for the legal order to exist and function in practice as a system of norms. ${ }^{9}$ Institutionalism, in other words, is the basic functional pre-requisite for the positive law to exist as a rule-bound order.

Both Arendt's and Fuller's theories of law, Rundle argues, hinge upon the 'legal institutional complex through which a subject experiences her relationship with authority. ${ }^{10}$ What is distinctive and distinctly valuable about the rule of law, according to Rundle, is the way it conditions this relationship with authority. Although half-heartedly pursuing these conditions in a normativistic vein, it is the connections between theory and political-institutional 'practice' rather than any free-floating prescriptivism that we are alerted to as central to the aims of the project.

This is because, in reality, the conditioning of authority is effected not by the rule of law itself but by a whole 'legal institutional complex,' which 'mediates' between a person and her political authority and which enables law to speak to individual agency. This institutional complex is not just 'an abstract philosophical commitment'; it must exist as a concrete, 'tangible' institutional reality, experienced by the subject herself in her daily life.

7 The term appears in one form or other no less than 40 times in Rundle's paper.

8 According to Loughlin, 'for institutionalism, order is not primarily the product of a set of rules. Norms or rules do not create order; they perform a regulatory function only on the basis of an already-established order,' Martin Loughlin, 'Nomos,' in Theorists of Constitutional Crisis: Oakeshott, Hayek and Schmitt on Law, Liberty and State, ed. Thomas Poole and David Dyzenhaus (Cambridge: Cambridge University Press, 2014, forthcoming), 19.

9 Loughlin, 'Nomos.'

10 Kristen Rundle, 'Legal Subjects and Juridical Persons: Developing Public Legal Theory Through Fuller and Arendt,' in this volume, 222. 
Although not a thinker usually associated with institutionalism, Arendt's key contribution to jurisprudence, Rundle suggests, is to provide an account of how the status of legal personhood emerges through a subject's interaction with this 'institutional complex,' a claim made plausible by focusing on a short section of The Origins of Totalitarianism. ${ }^{11}$ From this narrow focus, Rundle locates normative value in the conditions of juridical personhood, inferred from the fact that the totalitarian regime is compelled to eradicate it.

'What is it about this status of juridical personhood that is so resistant to the totalitarian mode that it must be broken down in order for totalitarian domination to be possible?' asks Rundle. 'Arendt's answer,' we learn, 'can be extrapolated from her account of the logic of the concentration camp,' which is at the centre of the 'institutional apparatus of totalitarianism.' ${ }^{\text {'2 }}$

Arendt's account of the significance of the camp depends on a distinction between 'the criminal' who has acted in a manner that is 'juridically defined,' and who retains juridical personhood because judged for his actions, and inmates of the totalitarian camps, such as political prisoners, judged merely for their identity or their opinions. Camp inmates are in an important sense in a worse position than the criminal, deprived of the normal guarantees of the law, because their recognition as individual centres of initiative is denied. ${ }^{13}$ This permits control by the state apparatus not only over the action but also the identity and opinions of persons.

It is, we are told, in the argument from totalitarianism that a prior idea of the 'juridical' can be discerned, prior in the sense that it is not exhausted by the norms of the positive law but instead is associated with a status conceived through the 'stabilities of law's wider institutional complex. ${ }^{14}$

The claim that Arendt's account of totalitarianism demonstrates an inner value in juridical personhood enables Rundle to align Arendt and Fuller. Although a totalitarian 'legality' might exist for Arendt - an awkward concession for Rundle -, there can be no totalitarianism that is compatible with the 'juridical person.' The juridical person must be destroyed by the totalitarian regime as a

11 This focus is at the expense of almost every other aspect of Arendt's work. Although Rundle cursorily addresses Hannah Arendt, On Revolution (New York: Penguin, 1963), there is no reference at all to Arendt's most systematic work, The Human Condition (Chicago: Chicago University Press, 1958). Nor is there any discussion of her work on the juridical categories of nomos or lex, which is developed in The Promise of Politics, ed. Jerome Kohn (New York: Schocken, 1959). Arendt's recently published and most 'jurisprudential' work, entitled 'The Great Tradition: Law and Power I and II' in the journal Social Research (2007 [1953]) is not discussed either. The problem with this rather narrow focus is that, although not a systematic thinker by any means, 'The Origins of Totalitarianism' is the least systematic of Arendt's major works, and was written before her theoretical categories and distinctions were fully developed.

12 Rundle, 'Legal Subjects and Juridical Persons,' 227.

13 It is surprising here that Rundle does not address aspects of our contemporary condition that illustrate such remarkably similar features to those of the Camps.

14 Rundle, 'Legal Subjects and Juridical Persons,' 230-231. 
necessary precursor to total domination. And because 'total domination' is incompatible with 'respect for personal agency,' we deduce, by contrast, 'a distinctly normative conception of "the juridical"'.

From Arendt's presentation of the juridical person in The Origins of Totalitarianism, Rundle draws the following conclusion:

'[t]he juridical person comes into being when political authority towards persons is expressed through an institutional order that bears attributes of stability such as predictability, intelligibility, and contestability. Through these attributes, the agents of a juridical order must recognize and speak to the persons with whom they engage as centres of initiative, and in doing so, necessarily limit their own authority in favour of that status. (...) [t]he "juridical" in Arendt designates a particular way of envisaging and treating the subjects of political authority, which is in turn constitutive of the status of juridical personhood, and, crucially both of these conditions exist only in so far as they are institutionally constituted and sustained through an appropriate ethos on the part of the relevant juridical actors. ${ }^{\text {'15 }}$

Juridical persons are engaged (by the 'agents of a juridical order') as centres of initiative, as responsible beings rather than merely acted upon by an authority, or moulded like putty into a certain form. That moment of institutional recognition constitutes the juridical person because the power of authority is constrained. It is through institutions and our interactions with them that we can therefore solve the mystery of law's normativity, or at least the limited normativity that comes from the capacity of institutions to stabilize our expectations and permit us to act for ourselves as responsible agents. The exceptional descent into totalitarianism reveals the value of legal personhood in normal times, a figure that can now represent an achievement and one that we endanger at our peril.

If this captures an important insight about the nature of governing regimes, it is doubtful that we can conclude much from the similarities between Fuller's celebration of the legal subject and Arendt's lament for the destruction of the juridical person. The doubt is not captured by the standard positivist repost to Fuller, that order can be predictably evil as much as predictably benign, or that law as an instrument can be used for good or for ill. The value of an institution that forecloses or at least frustrates the possibility of total control by an alien will is apparent. To identify this value solely or distinctively with the rule of law is, however, another matter - but that is not, in any case, Rundle's aim.

The challenge is more fundamental, but also more ambiguous and is to do with the nature and origins of the authority relationship. The origin of the juridical person and the manner in which status is bestowed thereon are opaque; it is a figure that 'comes into being' when political authority 'is expressed through' an institutional order that 'bears the attributes' of 'stability' and 'predictability.' 
How does a figure that has just come into being already witness an institutional order that bears the hallmarks of stability and predictability? Who are the mysterious 'agents' of the institutional-juridical order, and why does political authority emerge in that way in the first place? Political authority, we are told, is 'expressed'; it in turn 'envisages,' it has agents who 'engage,' and 'recognize' its subjects. But can one who is merely 'brought into being' and 'treated' by another, anonymous, institutional complex be anything other than a passive recipient of the law made by that 'complex'? What kind of a status is one that is merely 'conceived' (how? by whom?) through the stabilities of 'law's wider institutional complex'?

In Rundle's account, the juridical seems both fundamental to the very idea of such an institutional mode and yet secondary to the institutional recognition of actors (because 'constituted' by the recognition of individuals as juridical persons). Can this apparent circularity be redeemed through positing a 'mutual constitution' of the juridical person and the institutional mode of judging a person based on their actions?

Rundle's answer suggests the drawing of a potentially important distinction between what we can term an institutional structure and an institutional apparatus. The former sustains individual responsibility through legal procedures, for example, the procedures of the criminal law, which limit the power of an authority in its capacity to judge its citizens; the latter is constructed and used merely for the purpose of dominating individuals and knows no bounds, thereby dictating and eradicating selfhood and destroying public and private life. ${ }^{16}$

But how, in theory or in practice, do we know what is structure and what apparatus; when authority is conditioned and when, on the contrary, it dominates the individual? Unfortunately, although as Rundle laments, 'the features of this implied institutional structure are left unspecified by Arendt,' Rundle, too, leaves its features unspecified. There is a rather vague sense conveyed of the capacity of an institutional structure to stabilize expectations and sustain 'a predictable interaction between the person and authority.' But in one sense the inmate of the prison camp, deprived of all liberty, leads an utterly predictable life. And totalitarianism involves an ideological striving for complete certainty, depicting past, present and future as inevitably progressing towards a specific destiny.

So if it might be noted that totalitarianism is itself an attempt to impose total predictability on human affairs - even if the drive towards that end requires the unpredictability of arbitrary interference in order to obstruct political action and

16 The terminology is not always helpful here. The institutional 'apparatus' of totalitarianism, although suggestive of something more instrumental than an institutional 'complex,' remains 'institutional' in mode nonetheless, which suggests 'institutional' has little if any inherent normative aspect. Curiously Rundle makes no mention of current institutional examples, such as the Guantanamo Bay detention camp, massive state surveillance and secrecy and increasingly tragically contested flows of refugees and claims of asylum. 
contingency - it is unclear how in Rundle's account the institutional conditions for predictability emerge and what value predictability has.

An expectation of predictability cannot be generated by the stability of positive laws alone or by an expectation that an institutional structure or its agents will behave in a certain way. For stability depends in the first place upon some expectation that others will conform to the relevant norms; these are the conditions for the generation of any institutional structure. This is why Arendt looks in her work to distinctly human and pre-institutional actions of promising and forgiveness, as capable of mitigating the uncertainty and unpredictability of political life. ${ }^{17}$ But perfect stability, for Arendt, would be an illusory phenomenon, the mirror image of the totalitarian laws of motion towards a predetermined end.

It is, above all, Arendt's conception of 'power' as action in concert with others that is integral to freedom and politics, and to the maintenance of structures of authority that might defy totalitarianism. ${ }^{18}$ Power, for Arendt, is to be understood not as something possessed and exerted by one over many but, as distinct from violence or domination, as that which springs into being through our mutual appearance in action as equals, creating and sustaining a public world of politics. ${ }^{19}$ Only then might the stability that law facilitates have normative meaning, and only if it is a stability that permits and responds to action, contingency, and the radical new beginnings that characterize human affairs.

Although Rundle explicitly takes note of the political aspect of institutional order and of the significance of the creation of a status, and in particular, of the status of citizenship, ${ }^{20}$ the implications of statelessness, as emerge from Arendt's celebrated chapter on 'The Perplexities of the Rights of Man,' seem to have little direct bearing on the puzzle of institutionalism, beyond that which emerged from the account of totalitarian domination in the camps. ${ }^{21}$ For Rundle, statuscreation and the evaluation of personhood that attaches to it is 'institutionally driven. ${ }^{22}$ The theme of citizenship (what Arendt calls 'the right to have rights') is therefore ultimately secondary to 'institutional status'; the real significance of juridical personhood is found in the institutional framework. This 'framework' (or 'structure' or 'complex') is therefore presented both at a distance from the person

17 See, e.g., Arendt, The Human Condition, 237, 246.

18 See, e.g., Hannah Arendt, On Violence (New York: Harcourt, Brace and World, 1969).

19 Arendt, On Violence.

20 For Rundle, Arendt again turns to the example of the criminal to illustrate the significance of the juridical person, but now not merely as judged by his actions, but in terms of his position within the 'political-institutional order.'

21 'As the anomaly for whom the general law did not provide,' Arendt argues, it was better for the stateless person 'to become the anomaly for which it did provide, that of the criminal.' Hannah Arendt, The Origins of Totalitarianism (New York: Harcourt Brace, 1958), 286. According to Rundle, 'the surrounding institutional structure' is 'status-creating' in a distinctly positive sense' for the criminal. 'It transforms him from the status of a mere human, or worse, the "the scum of the earth," into someone "important enough to be informed of all the details of the law under which he will be tried."'

Rundle, 'Legal Subjects and Juridical Persons,' 226. 
- who merely experiences it - and at the same time as central to juridical status and to the subject's capacity for action, albeit for the limited purpose of being judged by another for one's action. ${ }^{23}$

But this, emphatically, is not the vita activa, in the Arendtian sense of creative, foundational or original action in concert with others. How, after all, does the status of legal personhood 'come into being' by virtue of the subject's interaction with it? ${ }^{24}$ This circularity points to a blind spot in Rundle's (and Fuller's) accounts of legal order, namely the absence of any conception of the foundation or constitution of political authority; in other words, of the origins of the juridical person and the creation and maintenance of the institutional framework that expresses and facilitates its freedom. The clue to this omission lies in the undifferentiated use of the term 'status,' its existence as a legal category is taken for granted by Rundle and Fuller; there is no account of how it is acquired or maintained and how it depends on the creation (and sometimes disruption) of order in the first place. ${ }^{25}$ Status recognition must not to be taken for granted; it is to be fought for and acquired through struggles for recognition, sometimes reformist, sometimes revolutionary.

\section{A 'bottom-up' or a 'top-down' jurisprudence?}

Although Rundle persists with the claim that an 'unexpected direction of normative legal theoretical thought ${ }^{\prime 2}$ emerges from Arendt's thought, Arendt's premises are distinctly at odds with the normativism of modern analytical jurisprudence - whether positivist or otherwise. To the extent that Arendt's unique approach can be usefully characterized as belonging to a tradition, it is phenomenological, unarticulated though this largely remains in her own work. The relevant questions for Arendt are how and by whom are conditions of freedom created in the first place; what can account for their appearance in the world? How, in other words, can we account for the experience and phenomenon of politics and why is it so central to the human condition? To adopt Rundle's terminology, Arendt's concern would be for the institutionalization or the collective generation of institutional power, ${ }^{27}$ not for the supposed normative value of an institutional structure supposed to be in place, requiring only proper administration to be maintained.

There is an ambiguity in Arendt's own presentation here; citizenship is important because qua citizen one is also then judged for one's opinions, in the sense that one's opinions matter, they count, but not in the sense that they matter for the criminal law.

24 Rundle, 'Legal Subjects and Juridical Persons,' 225.

25 Fuller gets close to reflecting on foundational issues indirectly in his educational fable of the Speluncian Explorers, in 'The Case of the Speluncean Explorers,' Harvard Law Review 62(4) (1949): 616-45.

26 Rundle, 'Legal Subjects and Juridical Persons,' 218.

27 This is captured nicely by Castoriadis's distinction between instituted and instituting power. See, e.g., Cornelius Castoriadis, Philosophy, Politics, Autonomy: Essays in Political Philosophy (Oxford: Oxford University Press, 1991). 
Arendtian action, or any other type of action germane to a political jurisprudence, cannot merely be found or experienced in a pre-existing institutional framework. Nor can the 'right to have rights' be secondary to 'institutional status.' On the contrary, such a framework or status can be created and maintained only through joint action and initiation. In this sense, to adopt the language of constitutional theory, action is akin to constituent rather than constituted power, based on principles that are constitutive rather than regulative of our social and political relations. ${ }^{28}$

Jürgen Habermas forcefully captures this creative aspect by construing Arendtian power 'neither as a potential for asserting one's own interests or for realizing collective goals, nor as the administrative power to implement collectively binding decisions, but rather as an authorising force expressed in "jurisgenesis" - the creation of legitimate law - and in the founding of institutions. ${ }^{29}$

Without this enquiry into power-founding, any account of institutionalism is inert and abstract. Institutional conditions just exist by virtue of 'the rule of law' and we come perilously close to saying that what the rule of law requires in order to function well is an institutional order that respects the rule of law. Rather than exploring the nature of the concrete social and political order that sustains or erodes them, let alone their origins, the conditions for the rule of law are essentially presupposed.

And yet for Arendt, experience tells of the contingency and fragility of juridical and political freedom, which requires action not only to be created, but also to be nourished and maintained. 'Mediation' between a person and authority is not enough. If we are implicitly referred back to 'Fuller's eight' (Rundle's expression for the desiderata of legality), then nothing public or participatory is offered from a political perspective; at most we get the conditions for the exercise of private autonomy.

If an 'institutional complex' - whatever that might mean in theory or in practice - is maintained by the mere 'experiencing' of authority, then political freedom is sidestepped. However benignly transmitted from sovereign to subject via the mediation of principles associated with the rule of law, authority remains alien, law is heteronomous. Persons here are mere subjects, passive receptacles of authority; envisioned by it, or even merely designated by the theorist rather than capable of action and initiation. Hannah Arendt and the Law, ed. Christopher McCorkindale and Marco Goldoni (Oxford, Hart, 2012). 
Whatever this might offer as a jurisprudential theory, it is neither 'the foundations of a "bottom-up" jurisprudence' nor a distinctly public idea of law. ${ }^{30}$ Whilst it might be true that there can be no meaningful conception of legal subjectivity until and unless one's status as an agent is rendered tangible through a legal institutional frame, it is for a bottom-up or public law jurisprudence to explain how this frame is created and maintained, and how it relates to individual and collective autonomy; and to do so in a way that does not give up on the question of the constitution of authority that lies at the roots of our political selfunderstanding, and of our juridical consciousness as the authors of our laws. ${ }^{31}$

In Rundle's reconstruction, the subject is conceived in the absence of political rights or of the capacity for political action. Although suggesting an 'Arendtian turn,' which helps to situate the explicitly 'public' character of legality, and which 'might lend itself to a distinctly public law jurisprudence,' institutionalism attends above all to questions of law's administration rather than its constitution. ${ }^{32}$

But it is precisely Arendt's conception of the public that resists any reduction of law to mere administration. Administration, for Arendt, is analogous to the decisions of the household (oikos) and its realm of economics. ${ }^{33}$ It is the antithesis of the public realm. Administration in its purest form of governmental bureaucracy is 'rule by nobody,' which represents the ultimate displacement of action and substitution of politics. And, indeed, for Arendt, 'is characteristic of all imperialist enterprise. $^{34}$

If it turns out that the legal subject or juridical person is merely an instance of law's administration, albeit we must suppose, an administration that satisfies, to some unspecified degree, 'Fuller's eight,' we end up with managerial direction with a plus sign. Rather than a bottom-up jurisprudence, we are offered a topdown jurisprudence, albeit one that makes demands in the name of the rule of

30 On the publicness of law, see recently, Neil Walker, 'On the Necessarily Public Character of Law,' in The Public Character of Law: Representations of the Political in Legal Discourse, ed. Harris Psarras et al. (Oxford: Hart Publishing, 2012).

31 Which is not to say that the idea of collective autonomy is a straightforward one.

32 In an earlier version of her paper, Rundle used the contrast between 'administration' and 'constitution.'

33 See esp. Chapter 2 of Human Condition. Once a substitute for action is found, politics then becomes mere administrative execution, analogous to the private economic decisions of the household. See Michael Wilkinson, 'Between Freedom and Law,' in Hannah Arendt and the Law, 50).

34 Arendt, The Origins of Totalitarianism, 213. As Patricia Owens notes, 'In governments by bureaucracy,' Arendt wrote, 'decrees appear in their naked purity as though they were no longer issued by powerful men, but were the incarnation of power itself and the administrator only its accidental agent' (OT, 244). Bureaucratic rule makes possible the thoughtless use of public power and diffuses responsibility. Although nobody is held responsible for such deaths, this 'nobody' still rules. All that remains, the 'one thing that counts [is] the brutal naked event itself' (OT, 245), the event of thousands of civilian deaths. See Patricia Owens, "How Dangerous it Can be to be Innocent": War and the Law in the Though of Hannah Arendt,' in Hannah Arendt and the Law, 269. 
law on those at the 'top,' whose rules must conform to certain desiderata if they are to deserve the name of law.

This may be a legitimate project, but it is emphatically not Arendt's. In Rundle's account, crucially, the juridical person emerges as a result of a process from which persons themselves are absent. In this image of law there can be no genuine 'reciprocity' between sovereign and subject. The juridical person depends on a pre-existing 'social order' or 'institutional complex' that is manufactured without her consent, whose existence can be taken for granted - without enquiry into how it comes into being and how it is in practice sustained.

On the contrary, law's institutional frame performs the role in Rundle's jurisprudence of what Arendt elsewhere labels 'the absolute,' that which is categorically denied to our individual or collective grasp. The term 'complex' is instructive here; it is complexity that now alienates us from our norms; institutions are extra-political features of our human condition. Rex may be disarmed, and even have his hands tied, but his head has yet to be cut off. Command may be conditioned, but it remains heteronomous; authority emerges from elsewhere.

\section{The Spectre of Hobbes}

But why, how and from where does authority emerge? Is there an implicit appeal to a Hobbesian social contract, standing at the fount of law's institutional complex? This would provide an account of how order is possible in the first place, an account of the origins of an authority that guarantees individual agency. It also, arguably, would account for the limits imposed on the Leviathan who governs through law. ${ }^{35}$ The legal institutional complex, Rundle's account suggests, not only generates the actual framework of authority, it also simultaneously limits its expression, because our autonomy is surrendered only on certain terms; these are the conditions implicit to the juridical person.

The irony of this implicit Hobbesianism is that for Arendt, as articulated with remarkable force in 'The Political Emancipation of the Bourgeoisie,' Hobbes is the ultimate anti-political bourgeois jurist, ${ }^{36}$ aligning private right and public good and identifying the purpose of the Commonwealth with the accumulation of power necessary for the security of property and of a personal, solitary life. If not quite lying at the 'origins' of totalitarianism, Hobbes's philosophy provides an

35 See, e.g., David Dyzenhaus, 'Hobbes on the Authority of the Law,' in Hobbes and the Law, ed. Thomas Poole and David Dyzenhaus (Cambridge: Cambridge University Press, 2012).

36 For Arendt, Hobbes starts from 'an unmatched insight into the political needs of the new social body of the rising bourgeoisie, whose fundamental belief in an unending process of property accumulation was about to eliminate all individual safety. Hobbes drew the necessary conclusions from social and economic behavior patterns when he proposed his revolutionary changes in political constitution. He outlined the only new body politic which could correspond to the new needs and interests of a new class. What he actually achieved was a picture of man as he ought to become and ought to behave in he wanted to fit into the coming bourgeois society' (Arendt, The Origins of Totalitarianism, 142). 
essential background element for understanding its later emergence, and the continuities (and discontinuities) between nineteenth-century imperialism and twentieth-century totalitarianism.

Deprived of political rights, Arendt argues, the Hobbesian individual 'to whom public life' manifests itself only 'in the guise of necessity,' acquires a new and increased interest in 'private life' and 'personal fate. ${ }^{37}$ There are no bonds of solidarity between men in Hobbes' account, only competitive instincts; there is no political citoyen, only the possessive, calculating individual. Since power in this Hobbesian scheme is only a means to an end,

'a community based solely on [such] power must decay in the calm of order and stability; its complete security reveals that it is built on sand. Only by acquiring more power can it guarantee the status quo; only by constantly extending its authority and only through the process of power accumulation can it remain stable. ${ }^{38}$

If power is merely instrumental to securing the stability necessary for private exchange and accumulation, then it becomes superfluous once that stability is achieved or can be achieved by other means. But in reality, unless it provides itself with new props from the outside, through the ever-present possibility of war with other states, such a community or commonwealth 'would collapse into the aimless, senseless chaos of the private interests from which it sprang. '39 The state, whose only justification is the increase and security of private power, comes to depend on the perceived need for war and conquest to justify its continued existence and expansion.

Since the Hobbesian vision is manifested in the constant accumulation of the new power required for a never-ending accumulation of property and capital - the power necessary for guaranteeing the stability of economic laws -, when capital accumulation reached its national limits, the power-accumulating process would have to operate and become organized outside national borders. Surplus capital would then require the institution of further political power to protect and defend its continued accumulation; such would be the demands of the owners of 'superfluous wealth. ${ }^{40}$ Arendt thus lays bare the reasons why nationalism, if understood merely as the sum total of individual interests, developed so clear a tendency towards imperialism, despite their apparent inner tension.

"The very fact that the "original sin" of "original accumulation" of capital would need additional sins to keep the system going was far more effective in 
persuading the bourgeoisie to shake off the restraints of Western tradition than either its philosopher [Hobbes] or its underworld [the mob]. ${ }^{41}$

But if Hobbes prefigures the strange alliance of bourgeoisie and mob, capitalist and imperialist ideology that would dominate the end of 'the long $19^{\text {th }}$ century' then what of modern race doctrines which are integral to the origins of totalitarianism, and which in their totalitarian form outline the organization 'through which humanity could carry the endless process of capital and power accumulation through to its logical end in self-destruction'? ${ }^{42}$

Although Hobbes's thought, Arendt claims, contains nothing of these totalitarian race doctrines directly, he had at least indirectly provided political thought with the pre-requisite for their development: 'the exclusion in principle of the idea of humanity,' an idea which constitutes 'the sole regulating' guide of international law. ${ }^{43}$

Is there anything in Fuller's account to distinguish the legal subject from Hobbes' egoistic man who desires freedom from personal interference by others? ${ }^{44}$ The desiderata of the rule of law contribute to an inquiry into the qualities of legal order that make possible liberty qua responsible agency. They constitute an ideal account of the juristic person, the legal subject, which depends on the compliance of the institutional structure with certain precepts captured by the motto 'the rule of law,' prescribing clear, coherent and stable rules. But responsible agency in this Fullerian sense could apply as much to corporations as to persons, conveying an image of man that is symbolized by the stability required for fruitful commercial exchange. Does Fuller's account then get its traction from the analogy with the contract or commodity form?

If so, this elevation of the 'commodity form' over the 'political form' of social relations erects a barrier between Arendt and Fuller. It celebrates formal equality before the law over the political freedom and equality to create and sustain the law. Fuller's (and Rundle's?) responsible agent is not then exercising political responsibility, or responsibility in the Arendtian sense at all, because such responsibility would be absolved if we relied on our strict legal relations and the formal protection of the law. Indeed an agent's responsibility is directed only towards authority in Fuller's (and Rundle's?) accounts, authority which may then

Arendt, The Origins of Totalitarianism, 156.

Arendt, The Origins of Totalitarianism, 156.

Arendt, The Origins of Totalitarianism, 157.

In a short piece, the first of a three lecture series, entitled 'The Case Against Freedom,' described by the editor as a 'striking departure' from Fuller's own previous jurisprudential thought, Fuller does gesture beyond the dichotomy of negative and positive freedom. But he does so only from the legislator's perspective, and only to assert that freedom is about 'allocating and implementing human choice.' See Fuller, The Principles of Social Order, 315-31. There is unfortunately no text for the second lecture, which asked what conception of human nature is necessary to make freedom a valid ideal, or the third, which asked whether known fact support such an ideal, as they consisted only of handwritten notes. 
judge the agent for her behaviour because her actions are prescribed or proscribed in clear and coherent terms.

And Fuller's casting of social order in this manner not only elides the problem of its nature and its creation but also - because, as history witnesses, sustaining social order in the face of contingencies is frequently claimed to require sacrificing one or some desiderata in order to maintain others, as when legal certainty is sacrificed for the sake of long-term stability - it ignores the tensions and even contradictions between the maintenance of social order and the rule of law and between the values associated with the rule of law itself. ${ }^{45}$ Stability, one must always ask, for whom? The double irony here is that the commodification upon which market society depends and contractual exchange prospers is an inherently unstable social phenomenon. ${ }^{46}$

If for Rundle legal structure maintains the possibility of security, private autonomy and personal responsibility, for Arendt it is the reverse: joint action and initiative make the rule of law - as opposed to domination - possible. We must be responsible to others and ourselves for the law, not only to the law and its agents for our individual behaviour. A narrow reliance on law as a normative order - however closely respecting Fuller's ideal of legality - is the beginning of the end for the flourishing of political freedom. It is through joint action that law comes to be institutionalized in the first place, and it is through joint action that it will be nourished and maintained in the long run.

\section{The idea of political freedom}

If Fuller and Rundle present us with the outline of an account of the law that makes political rule legitimate, then 'from the other end,' we need to consider the inverse relation; of the politics that makes the rule of law possible. The politics, in other words, that lies at the origins of, and maintains, the positive legal order as an effective, functioning and legitimate system of norms and set of practices. Politics, for Arendt, is undoubtedly the more basic of these categories, because it stems from a fundamental aspect of the human condition, the condition of plurality, 'the fact that men, and not Man, walk the earth and inhabit the world. ${ }^{\text {47 }}$ Law, in its most basic sense, elides difference and plurality.

An Arendtian jurisprudence must therefore insist on interrogating the interdependence of law and politics in a foundational manner, which means exploring the constitution of the polity in a twofold sense: not only the laws that are constituted but the activity of constituting authority.

45 Fuller notes that his own desiderata of the rule of law must be 'combined and recombined with something like an economic calculation' in order to be maximized; Fuller, The Morality of Law, 104.

46 See recently, Wolfgang Streeck, 'Taking Capitalism Seriously,' Socio-Economic Review 9(1) (2011): 137-67.

47 Arendt, The Human Condition, 7. 
It is not the passive legal subject or juridical person but the active citizen that is key to Arendt's understanding of freedom and the world of politics; and activity here is understood not in the bourgeois sense of being able to pursue an individual life plan or accumulate wealth unhindered, but in the political sense of action, of new beginnings and initiatives in concert with others. As Arendt puts it in On Revolution: the act of foundation following the American Revolution could operate as a 'fountain of authority,' just as the word constitution carries a twofold meaning; it is both the act of constituting and the result of what is constituted. 'Crucial to any understanding of revolutions in the modern age,' Arendt suggests, 'is that the idea of freedom and the experience of a new beginning should coincide.' 48

Unique about modern revolution is that freedom is conceived not merely as a mental category of thought, judgment, or will, but as a category of action and, furthermore, in a manner that supersedes the weak sense of mere 'liberation' from the constraints of an oppressive regime. It emerges in the strong sense of revealing our capacity to create a 'new beginning' for political freedom, as well as institutions to preserve a space in which freedom can be exercised for posterity. ${ }^{49}$

Of the self-conception of the American founders, the record of the American Revolution speaks an entirely clear, unambiguous language: it was not constitutionalism in the sense of 'limited,' lawful government that preoccupied them. ${ }^{50}$ The main question for the revolutionary was not, "how to limit power but how to establish it, not how to limit government but how to found a new one. ${ }^{51}$ Arendt continues:

'The very fact that the men of the American revolution thought of themselves as founders indicated the extent to which they must have known that it would be the act of foundation itself, rather than an Immortal Legislator (...) or self-evident truth or any other transcendent (...) source, which eventually would become the fountain of authority in the new body politic (...) It is futile to search for an absolute to break the vicious circle in which all beginning is inevitably caught, because this absolute lies in the very act of beginning itself. ${ }^{52}$

The vicious circle of the legality of the new law and the legitimacy of the new power is made virtuous not by positing an absolute source of authority, whether sovereign command or institutional complex, but by developing a principle from Machiavelli, the awareness that a new beginning could actually occur in historical time as a political phenomenon, that it could be, in Arendt's words, 'the result of what men had done and what they could consciously set out to do,' emerges only in the course of the late eighteenth century revolutions (Arendt, On Revolution, 46).

50 Arendt, On Revolution, 147.

51 Arendt, On Revolution, 148.

52 Arendt, On Revolution, 205. 
the act of beginning, and one which might be augmented through repeated instances of concerted action itself, of acting on that principle.

To capture the novelty of Arendtian freedom, it is emphatically not a phenomenon of the 'will,' a question of one's personal freedom to choose from a set of already existing alternatives, 'x, y or z,' or of having a framework in place to guarantee this choice from the interference of another. It is not about being able to choose our ultimate goals or the absence of interference (or domination) by others in this choice and the means to pursue it.

Freedom, for Arendt, is the political experience of the 'Yes, we can' rather than the 'Yes, I will." ${ }^{53}$ It is the capacity to 'call something into being which did not exist before,' something that is not given 'even as an object of cognition.' 54 This conception of freedom reflects the significance of the event of 'natality' for the human condition.

'The new beginning inherent in birth,' Arendt notes, 'can make itself felt in the world only because the newcomer possesses the capacity of beginning something anew, that is, of acting,' and in so doing of performing the unexpected and even the 'infinitely improbable. ${ }^{55}$ It is only in the course of acting and speaking in the public realm that men reveal this potential to the world by revealing who they are, exercising their freedom by disclosing their 'unique personal identities, ${ }^{56}$ a potential which is utterly destroyed by totalitarianism but is also occluded by liberal individualism.

The loss of this public realm was ultimately the reason for the failure of the American revolutionary tradition, which is lamented by Arendt as she gazes back from the middle of the twentieth century. Although initially more successful than the French, due in large part to the separation of power and authority in the US constitution, the failure to institutionalize political freedom is the 'lost treasure' of the American revolution. This ambivalence reflects an undoubted tension in Arendt's thought, which makes life difficult for the legal philosopher attempting to interpret it. It is captured in the recurrent tension between revolution and con-

53 Arendt contrasts freedom as the 'I will' with the freedom as the 'I can,' Between Past and Future (London: Penguin, 1954), 157-61. But since political freedom is experienced in concert with others, the notion of the 'We can' presents a more apposite contrast.

54 Arendt, Between Past and Future, 150.

55 Arendt, Human Condition, 9, 178. Natality, she adds, 'may be the central category of (...) political thought (...) Of the three aspects of the vita activa, action has the closest connection with the human condition of natality.'

56 Human Condition, 179. 'It is in the nature of beginning that something new is started which cannot be expected from whatever may have happened before. This character of startling unexpectedness is inherent in all beginnings and in all origins (...) The fact that man is capable of action means that the unexpected can be expected from him, that he is able to perform what is infinitely improbable' (Human Condition, 177-8). 
stitution, between extraordinary and normal politics, institutionalized power and the power to institutionalize. This is a tension that admits no easy resolution. ${ }^{57}$

But because of this tension, Arendt's work necessarily and unequivocally sits uncomfortably against the assumption of a standing constitutional tradition, whose existence and stability is taken for granted. There are no guarantees, for Arendt, certainly no guarantees of 'order' or 'predictability.' Neither can we dispose of the significance of political and even revolutionary action for the founding of new regimes and the ties necessary for them to flourish. It is for this reason that Arendt speaks with such admiration about the Roman lex, which signifies the act of engaging with one another through promises, mutual ties and pledges and avoids the absolutism of sovereign command, as well as the prepolitical connotations of nomos. Is it here that one might seek to develop a political jurisprudence that avoids Schmitt's decisionism and institutionalism? ${ }^{58}$

\section{Political jurisprudence}

A political jurisprudence cannot ignore the difference in kind between moral and political right or, in subjective terminology, between the right of the juridicalmoral person and the right of the juridical-political person. Attempts to conflate these two kinds into the vernacular of a 'political-morality' will elide significant distinctions and create confusion and distortion. ${ }^{59}$ The significance of this distinction in human rights discourse, between political as opposed to moral right, becomes clear, for example, from Arendt's discussion of equality. 'We are not born equal,' she notes; 'we become equal as members of a group on the strength of our decision to guarantee ourselves mutually equal rights.' ${ }^{\prime} 0$ This is why the right to citizenship or 'right to have rights,' lost by the stateless to devastating effect, is so crucial in understanding the inadequacy of the so called 'rights of man.'

57 For an attempt in American constitutional history, see Bruce Ackerman, We, The People: Foundations (Cambridge: Harvard University Press, 1991).

58 For an exploration of this, and Arendt's (ambiguous) preference for lex over nomos, see Wilkinson, 'Between Freedom and Law.'

59 The difference is elegantly illustrated in Hans Lindahl's recent work exploring the politics of what he calls 'a-legality,' and specifically his deconstruction of the human rights literature. Rejecting both the Habermasian view of human rights as inherently juridical, the logical conclusion of which is a 'world state' or some variation which might enforce them, and Benhabib's (Kantian) view of human rights as universal moral rights 'of others' which are a degree less concrete than when guaranteed legally in the state legal order, but which can be pressed against those claims, Lindahl shows the thoroughly political character of human rights through exposing their relation to claims of collective agency: 'there can be no passage from human rights as moral rights to fundamental rights as legal rights, unless a manifold of individuals are deemed to take up the first-person plural perspective of a "we." See Hans Lindahl, Fault Lines of Globalization: Legal Order and a Politics of A-Legality (Oxford: Oxford University Press, 2013).

Arendt, The Origin of Totalitarianism, 301. See Lindahl, Fault Lines of Globalization, for analysis. 
What might be called the jus in lex can be presented as a political rather than a moral right, or in terms of what has been called droit politique, based, in one account, on prudential concerns of creating and maintaining political order. ${ }^{61}$ Whether one might then seek to elaborate a moral value in this form of political right depends on what is meant by moral. To avoid confusion it might rather be classified as contingent rather than categorical; even if based on a fundamental fact about human nature, that, for instance, man is a 'political animal' as Aristotle insisted, the morality of law depends on the virtues of rule, which are of course demonstrated only contingently. ${ }^{62}$ And then the conceptual and normative investigation can turn to the phenomenon and legitimacy of rule itself, in the way for example the neo-republican tradition has attempted to reconstruct an alternative conception of freedom and placed the question of political legitimacy alongside and in some sense prior to that of justice. ${ }^{63}$

Might we identify a universal prescription, valid to all human beings in all times and all places: go forth and make law and a legal order that conforms (to some unspecified degree) to 'Fuller's eight'? Fuller's answer to this - an 'emphatic, though qualified, procedural natural law',$-{ }^{64}$ hinges on the 'seemingly naive belief' that 'coherence and goodness have more affinity than coherence and evil.' 65 This is a leap of faith that would be resisted by an Arendtian philosophy.

The focus for Fuller is on the relationship between power and those subject to it, which implies a concept of ruler and ruled that is straightforwardly and importantly non- and even anti-Arendtian, both in tone and in substance. Although Fuller considers the rule of law to have a purposive element, to be an association geared towards a common aim, the overall enterprise of 'subjecting human conduct to the governance of rules' is entirely passive from a political perspective. Whereas for Fuller law is non-instrumentally valuable, for Arendt it is political action that must be understood non-instrumentally, and this is so because of basic features of the human condition, plurality and natality.

Arendt's account of totalitarianism, to be sure, identifies the destruction of the juridical person as a crucial moment in that regime's progressive domination. But

61 See, esp., Martin Loughlin, The Idea of Public Law (Oxford: Oxford University Press, 2003).

62 Raz conveys this ambiguity about the moral virtue of the rule of law by claiming that the rule of law is a negative virtue. Even if we need to expand on that formulation, as Waldron notes, to say that the rule of law negates certain potential dangers inherent in any form of political rule, the case is not yet made out that the rule of law is a categorically moral institution. See Joseph Raz, 'The Rule of Law and Its Virtue,' in The Authority of Law (Oxford: Oxford University Press, 2009) and Jeremy Waldron, 'The Concept and the Rule of Law,' Georgia Law Review 43 (2008): 1-61.

63 See, e.g., Phillip Pettit, 'Justice and Legitimacy in Republican Perspective,' Current Legal Problems 65 (2012): 59-82.

64 Fuller, The Morality of Law, 96.

65 Lon L. Fuller, 'Positivism and Fidelity to Law: A Reply to Professor Hart,' Harvard Law Review 71(4) (1958): 630-72, at 636. This has been described as 'Fuller's faith,' by Paul Cliteur in Willem J. Witteveen and Wibren van der Burg, eds, Rediscovering Fuller: Essays on Implicit Law and Institutional Design (Amsterdam: Amsterdam University Press, 1999), 100-24 at 117. But it is far removed from any concern of Hannah Arendt's with the juridical person. 
far from being such an 'obstacle to totalitarianism' as Rundle suggests, it is in fact the first form of personhood to crumble, after which the moral and then the individual person is finally and painfully obliterated. If the killing of the juridical person helps totalitarianism to run its course, it is with the obliteration of the moral and individual person that totalitarianism is defined. What truly distinguishes totalitarianism, it might be argued, is the destruction of the political person, because it erases individuality, identity, and plurality, and in obstructing the possibility of concerted action, erases the idea of the public on which such action depends.

The focus for Arendt is, in any case, not on the concept or nature but on the origins of totalitarianism. For Arendt, aspects of totalitarian rule are prefigured in imperialism, bureaucratic rule by decree, and the anti-humanism that, as we explored above, can be traced back to the bourgeois philosophy of Thomas Hobbes, ${ }^{66}$ not in a direct line of causation, but in terms of uncovering common threads and pre-existing elements. The political person can be occluded by a liberal legalistic focus on the impersonal rule of law as well as by a totalitarian focus on the impersonal law of rule.

Power in concert with others, which is always fragile, is quashed by the fear of tyranny and the violence of totalitarian regimes. But it is also eroded by a 'topdown' conception of authority, which presents a view of the person as merely object to be 'acted upon,' or 'subject to be commanded' and 'instrumentalized for an authority's purpose.' It is this view of the human agent - which elides a distinct view of the person as free and equal in a political sense - that the tradition of legal normativism (as much as legal positivism) ultimately still fails to transcend.

\section{Conclusion}

Does Fuller's alternative therefore offer significantly more than its positivist rival? From an Arendtian perspective, an affirmative answer is doubtful. Arendt's critique of the command tradition, which, as Rundle notes, is one she shared with Fuller, goes far deeper than Fuller's critique of its neglect of the rule of law, institutional mediation and reciprocity between sovereign and subject. Arendt's critique of this tradition is based primarily on its inability to conceive of power in anything other than a hierarchical, dominating form:

'When the Athenian city-state called its constitution an isonomy or the Romans spoke of the civitas as their form of government, they had in mind a concept of power which did not rely upon the command-obedience relationship. It is to these examples that the men of the $18^{\text {th }}$ century revolutions turned when they ransacked the archives of antiquity and constituted a 
republic, a form of government, where the rule of law, resting on the power of the people, would put an end to the rule of man over man.' 67

A development of Arendt's critique of the command conception of law must surpass a criticism of the shallow legal positivism that emerges out of the tradition of Bentham and Austin; it must build on a deeper critique of the understanding in the Western philosophical tradition from Plato to Marx of the concepts of power and freedom, a tradition where power is viewed as a thing possessed by some to dominate others and freedom is sought from politics.

The idea of an institutional complex is, like the more basic positivist idea of command it attempts to surpass, destined to avoid the uncertainties of political action in the conditions of human plurality. Like legal positivism, it marks the desire to escape from politics, and therefore from freedom, altogether. The "hallmark' of all such escapes from politics is, says Arendt, 'the concept of rule,' because it implies 'that men can lawfully and politically live together only when some are entitled to command and others forced to obey.' ${ }^{8}$ That remains the case however much the laws of rule are conditioned by institutional guarantees or desiderata of predictability and stability.

The commonplace notion that political community is necessarily constituted in rule-based fashion rests on a suspicion of action and the wish for it to be displaced. Rundle's renewal of Fuller's jurisprudence, with its focus on the administration of power rather than its constitution, further displaces the political, substituted now for an institutionalism that obscures the value of political freedom and occludes the phenomena of action, initiative and collective autonomy. A jurisprudence that aims to contribute to the development of legal theory in its distinctly public, or political, aspect must confront these phenomena head-on. 